\title{
TRANSITION AND EVOLUTION OF INFORMATION AT THE MICROSCOPIC LEVEL
}

DOI: $10.36724 / 2072-8735-202$ |-|5-5-62-66

Aleksey V. Yudenkov,

Smolensk State Academy of Physical Culture, Sport

and Tourism, Smolensk, Russia, aleks-ydenkov@mail.ru

Aleksandr M. Volodchenkov,

Smolensk Branch of Plekhanov Russian University

of Economics, Smolensk, Russia, alexmw20I2@yandex.ru

Manuscript received 14 December 2020;

Accepted 26 January 2021

Liliya P. Rimskaya,

Smolensk Branch of Plekhanov Russian University

of Economics, Smolensk, Russia, lilirimska@yandex.ru

Keywords: phase space, Markovian process, quantum field theory

\begin{abstract}
A simultaneous development of the fundamental research areas of the information theory is needed for efficient development in the information technologies. It is known that for the complicated macroscopic systems information evolution may be shaped on the basis of the principal thermodynamics laws (the second law of thermodynamics, etc). At the same time it is not known whether the fundamentals of the information theory for the macroscopic systems may be applicable to the microscopic systems. The study works out a mathematic model of the discrete phase space adapted to describing the evolution of information (entropy) of the microscopic systems. The discrete phase-space model rests on the indeterminacy principle and fundamental properties of the discrete continuous-time Markovian systems. The Kolmogorov equations represent the main mathematical tools technique. The suggested model refers to the smallest metric scale when the external macroscopic observation is possible. This scale can be viewed as a quasiclassical level. The research results are the following. The structure of the phase space of the elementary signal is revealed. It is demonstrated that the entropy of the microscopic systems increases, i.e. for the microscopic systems the second law of thermodynamics is true. There has been demonstrated transition from the microscopic model to the macroscopic one thus proving the former's adequacy. The discrete phase-space model is promising in the aspect of further development. For example, it can be applied to the physical systems "particle - field". The approach represented by the model will allow to study electromagnetic and gravity fields at the quasiclassical level. The above model of the discrete phase space and its application in the study of the evolution of the microscopic systems is a proprietary design of the authors.
\end{abstract}

Information about authors:

Aleksey V. Yudenkov, Head of the Department of Management and Sciences, Doctor of Physics and Mathematics, professor, Smolensk State Academy of Physical Culture, Sport and Tourism, Smolensk, Russia

Aleksandr M. Volodchenkov, Head of the Department of Sciences and Humanities, Candidate of Physics and Mathematics, associate professor, Smolensk Branch of Plekhanov Russian University of Economics, Smolensk, Russia,

Liliya P. Rimskaya, Professor of the Department of Management and Customs, Candidate of Physics and Mathematics, associate professor, Smolensk Branch of Plekhanov Russian University of Economics, Smolensk, Russia

Для цитирования:

Юденков А.В., Володченков А.М., Римская Л.П. Передача и эволюция информации на микроскопическом уровне // Т-Сотт: Телекоммуникации и транспорт. 202I. Том I5. №5. С. 62-66.

For citation:

Yudenkov A.V., Volodchenkov A.M., Rimskaya L.P. (202I)Transition and evolution of information at the microscopic level. T-Comm, vol. I5, no.5, pp. 62-66. (in Russian) 


\section{Introduction}

The interconnection of thermodynamics and the information theory of the complex systems has played an important role in the development of the latter. One of the most important properties of information, that is, tend to its largest value, is directly connected with the second law of thermodynamics. The effective information maximum method used to seek stable states and control values is in many ways similar to the method of optimization of the thermodynamic potential in the Landau theory of unbalanced phase transitions ([11], p.72, p. 103).

The efficiency of the use of the known thermodynamic models in the information theory of the complex systems is explained by the fact that such systems consist of rather a large number of simpler systems. This enables to use them with medium macroscopic (thermodynamic) characteristics, in other words to apply determinate mathematical models in real-world contexts.

Though it may seem strange but transition and dissemination of information in microscopic systems have not yet been fully studied ([7] p.51). It may be mainly explained by the fact that the known mathematic models both determinate continuous-time and stochastic discrete stay ineffective in terms of the macroscopic observer and microscopic system.

The study aims at developing a mathematical model for adequate description of the information evolution on the microscopic system relating to the microscopic observer. Also some realworld applications of the model will be demonstrated.

\section{Methods}

First let us decide on a scale model. In many applications of complex systems it is enough to assume that the microscopic systems constituting a macroscopic system follow the classical physics laws, for instance a known law of the ideal gas. For our study such a scale model will be too large and will not allow to distinguish time direction. On the other hand if we switch over to the quantum level then the evolution of the microscopic system falls beyond the reach of the microscopic observer. Thus, the model will be effective while working on the border scale of the classic and quantum physics. The quasiclassical level meets the above conditions ([8] p. 202, [10] p. 344).

Let the quasiclassical level be such a scale when the energy unaccounted for in the contact with a macroscopic system is related to the time of observation by the formula

$$
\Delta E \Delta t=h \text {. }
$$

Where $\mathrm{h}$ is the Plank constant.

If we switch to the momentum representation, then formula (1) can be written as

$$
\Delta p \Delta x=h .
$$

Physical and informational aspects of relations (1) and (2) can be explained with the help of the Compton effect on an electron ([5] p.126). In addition let us relate the coordinate system to a particle. To receive minimum information a macroscopic observer should act on a particle. The simplest is to scatter a photon on a particle of energy hv and momentum $h v / c$ (where $\mathrm{c}$ is a light speed). Briefly a scattered photon is represented in Fig. 1.

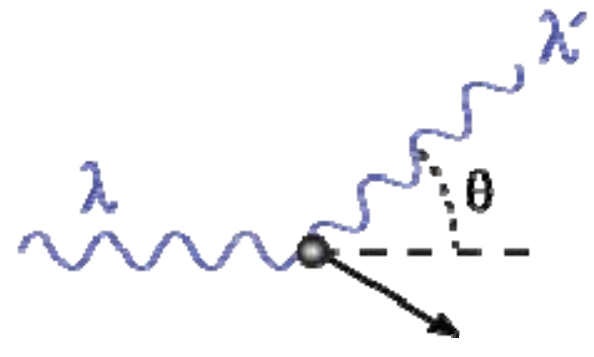

Figure 1. Photon and electron interaction (Compton effect)

The indeterminacy of the electron location will be in the region of $\lambda$ (that is a photon wavelength), the momentum indeterminacy will be in the region of (a photon momentum). From the above reasoning, the most efficient estimate of the electron phase volume is

$$
\Delta p \Delta x \sim h / 2 .
$$

A more accurate measurement of a particle with mass than formula (3) is impossible in principle.

Therefore, the Plank constant determines a minimum phase volume of a particle and minimum information (in this study we presuppose that the phase space of a particle coincides with its information space).

Now we lay down essentials of a mathematical model applicable to the information space of a micro-system.

1. A particle and its field are a unified physical system. A system is evolving in a phase space.

2. Due to the Heisenberg indeterminacy principle a phase space is indiscrete. The volume of a unit cell in a phase space is $h^{s}(2)$, (3). Here $s$ is a number of degrees of freedom.

3. On a discrete phase space introduce a symplectic structure ([1] p. 152).

In this case the symplectic structure will be discrete. That is,

$$
h \sim \Delta \omega^{2}=\Delta p_{1} \wedge \Delta q_{1}+\ldots+\Delta p_{3} \wedge \Delta q_{3} .
$$

From the relation (4) follows that a minimum value of a pseudo vector correlates to the Plank constant.

4. Evolution of a particle on the phase space happens at the cost of fluctuation of the energy $\Delta \mathrm{E}$ (as a consequence of the Heisenberg indeterminacy principle) and represents a discrete continuous-time Markovian process.

Let us determine the structure of an information space of the microscopic system. It is possible to distinguish a border cell of a phase space and the inner subspace.

In case with a border cell from relation (1) we have

$\Delta E \tau=h v \tau$.

From the law of conservation of momentum we have:

$\Delta p \Delta q=2 h v \frac{\lambda}{c}$

Therefore

$$
\frac{\Delta E}{\Delta p}=\text { const }=c / 2 \text {. }
$$


The result arrived at indicates that a border quantum of a phase space is massless. It will move at a constant determined speed. The mass of a particle will be realized only in the inner portion of a phase space.

Notice one fact. According to formula (5), one half of the particle's energy falls on the border of a phase space. The other half spreads over the internal portion of the phase space.

The evolution of the inner portion of the electron phase space is featured in Fig. 2.

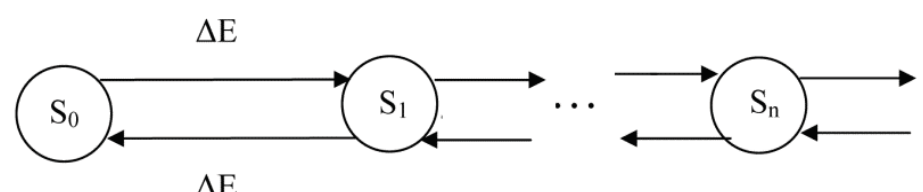

Figure 2. Electron evolution graph on a discrete phase space (subspace)

The process of the electron evolution on the phase space coincides with the process known in the theory of stochastic processes, a death and multiplication process ([2] p. 177).

Application of a discrete phase-space mathematical model leads to the important conclusion. As the existence condition of a steady mode is not fulfilled (mentioned density $\rho=1$ ) ([2] p. 363), it follows that the phase space and micro-system entropy will grow. This corresponds to the second law of thermodynamics formulated for the macroscopic systems.

Research [8] demonstrates in a slightly different way that under the number of space dimensions $\mathrm{n} \geq 2$ the system evolution becomes transient. The only case of reflexity of a system is under $\mathrm{n}=1$.

Within the suggested discrete mathematical model the situation with $n=1$ can be interpreted as follows. Here the order of a hypothetic system is less than the signal order with the help of which it is detected. A photon can be considered a twodimensional system ([5] p. 25). Thus in evolution a unidimensional particle will not only increase its external phase space but also occupy the free subspace of the cells generated by the photon. The Brownian motion will make this occupation proportional. As a result the process «functioning» can be conceived of as a graph represented in Fig. 3.

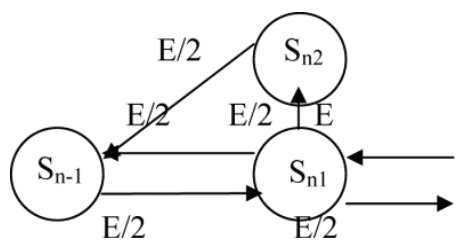

Figure 3. Functioning of a phase cell in a steady mode

If we do not study the internal structure of a cell, then the evolution graph of a phase space of a one-dimensional system will be as in Fig. 4.

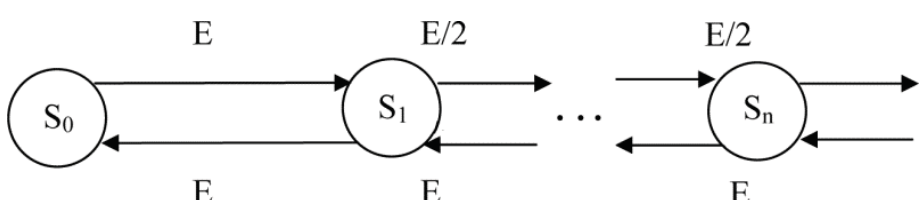

Figure 4. Evolution of a one-dimensional system on a phase space of an electron
For this process there is a steady mode of functioning. That is, a one-dimensional system generates stable structures on a phase space. After the system has been detected by the observer, it remains in the bounded domain of the phase space. It is easy to evaluate mathematical expectation of the number of cells occupied by a one-dimensional elementary system.

$$
E(S)=\frac{3}{2} h
$$

Transition from microscopic to macroscopic modeling. While transiting from the quasiclassical to macroscopic level it should be noticed that dimensions of an elementary phase cell are rather small as related to the external observer. So on the assumption of the observation being long enough, a discrete model of the phase space can be substituted with a continuoustime model. In this situation a particle will move in accordance with the Ito equation for the Brownian motion.

To proceed further we will make use of the following definitions and properties ([8], ch.7)

Definition 1. A diffuse homogeneous in time Ito process is pure random, satisfying stochastic differential equation

$$
\begin{aligned}
& d X_{t}=v\left(t, X_{t}\right) d t+\sigma\left(t, X_{t}\right) d B_{t}, \\
& t \geq \tau \geq 0, X_{t}=x
\end{aligned}
$$

Where $\mathrm{B}_{\mathrm{t}}$ is a $m$-dimensional Brownian motion; functions $v(\mathrm{x})$ and $\sigma(\mathrm{x})$ are subject to the condition

$$
\begin{aligned}
& |b(x)-b(y)|+|\sigma(x)-\sigma(y)| \leq D|x-y|, \\
& x, y \in R^{n} \\
& D=\text { const. }
\end{aligned}
$$

Here $v\left(t, X_{t}\right)=0, \sigma\left(t, X_{t}\right)=1$.

Now make use of the interrelation between the Ito diffuse process and its characteristic operator.

Definition 2. Let $\{X(t)\}$ be a diffuse Ito process. A characteristic operator $A$ of process $\{X(t)\}$ is determined by formula

$$
A f(x)=\lim _{U \rightarrow x} \frac{M^{x}\left[f\left(X\left(\tau_{U}\right)\right)\right]-f(x)}{M^{x}\left(\tau_{U}\right)} .
$$

Here $U$ stands for sets $U_{k}$, shrinking to point $x$ in that $U_{k+1} \subset U_{k}$ and $\bigcap_{k} U_{k}=\{x\} ; \tau_{U}=\inf \{t>0, X(t) \notin U\}$ is the first exit time out of $U$ for process $\{X(t)\}, M^{x}($.$) is mathemat-$ ical expectation.

If a function set lies within $C^{2}$, then it is true that:

Theorem 1. If $f \in C^{2}$, then it implies the existence of lim (7) and true is the following correlation

$$
A f(S)=\sum_{i} b_{i} \frac{\partial f}{\partial x_{i}}+\frac{1}{2} \sum_{i j}\left(\sigma \sigma^{T}\right)_{i j} \frac{\partial^{2} f}{\partial x_{i} \partial x_{j}} .
$$


Taking this into account, from (6) and (7) for an elementary particle in a phase space we have

$$
A f(S)=\Delta f \text {. }
$$

Equation (8) shows that in extreme case and long-time, the discrete model of a phase space goes into a continuous-time model resembling the static field model which is described by the elliptical equation.

As an example, let us take the evolution of the phase space of an unbound electron. In this case in equation $f(S)=\rho(S, t) S$,

have:

$$
\Delta f(r)=k \rho
$$

Here $\rho$ is electric charge density, $k$ is invariable. Then correlation (9) coincides with the Gaussian law, equal in case with a centrally-symmetric field to the Coulomb’s law.

\section{Conclusions}

The outlined mathematical model of a discrete phase space has the ability to quite adequately describe the process of information change (entropy) in the microscopic system.

The chosen level of description is extremum for the interaction of a microscopic system and a macroscopic observer. Application of the discrete model of the phase space gives a number of meaningful results. The investigation gives proof of the entropy growth in the microscopic system (analogous to the second law of thermodynamics).

A separate study of the evolution of a one-dimensional microscopic system in the multidimensional space has been conducted. It demonstrates that in a one-dimensional case there exists a steady-mode functioning for a system.

In the study there has been presented a transition from the stochastic mathematical model of a discrete phase space to a continuous-time determined field model.

The latter predetermines one of the prospective application of the suggested model. That is, the discrete phase-space model is transitional between classical field equations and the quantum approach. Thus the model may be applied for development of the quantum gravity-field theory.

The main difficulty in the development of the quantum gravity theory, as is known, resides in the fact that short-range and high energy gravity force is too strong. ([9],[17],[18]). The system here is concealed from the observer beyond the event horizon ([4],[14],[15],[16]). The discrete phase-space model has an advantageous approach to the elementary particle as «scattered» on the elementary phase cell.

This completely eliminates singularities interfering with the development of the theory. In particular, the suggested mathematical model enables a consistent definition of a graviton as a quantum bearer of the gravity field as well as an original physical interpretation of the constant of thin structure.

\section{Originality}

The discrete mathematical model of a phase space has been developed by the authors ([3],[12]). Some results obtained from the application of the above model are put forth in [12], [13]. The observations set out in the article are new.

\section{References}

1. V. I. Arnol'd (1989). Mathematical methods of classical mechnics (Matematicheskie metody klassicheskoj mehaniki). 3-d edition. Moscow: Nauka. $472 \mathrm{p}$

2. E. S.Ventcel', L. A. Ovcharov (2000). Probability theory and its engineering application. 2-nd edition. Moscow: Vysshaja shkola, 2000. 480 p.

3. A.M. Volodchenkov, A.V. Judenkov, L.P. Rimskaja (2017). Informational quantization in the symplectic manifold. Collect. works: Social and economic development of the region: practice, problems, innovations. VI International research-to-practice conference of 'Plekhanov spring' and the University's 110-th anniversary. Ministerstvo obrazovanija i nauki rossijskoj federacii; Rossijskij jekonomicheskij universitet imeni G.V. Plehanova Smolenskij filial. P. 41-46.

4. G. E. Gorelik (2005). Matvey Bronshtein and quantum gravity. On the $70^{\text {th }}$ year of the problem unsolved. Achievements of physics. Vol. 175. No. 10. P. 1093-1108.

5. V. N. Gribov (2001). Quantum electrodynamics. Izhevsk: RHD. 288 p. ISBN 5-93972-089-7.

6. L.D. Landau, E. M. Lifshic (1989). Theoretical mechanics. Vol. 3. Quantum mechanics. Moscow: Nauka. 768 p.

7. L.D. Landau, E. M. Lifshic (1989). Theoretical mechanics. Vol.5. Statistics mechanics. Moscow: Nauka. 626 p.

8. B. Oksendal' (2003). Stochastic differential equations. Moscow: Mir, Izdatel'stvo AST. 408 p.

9. L. B. Okun' (1988). Physics of elementary particles. Moscow: Nauka. 272 p. ISBN 5-02-013824-X

10. R. Penrouz (2007). The Road to Reality: A Complete Guide to the Laws of the Universe. Transl. by A. R. Logunova, Je. M. Jepshtejna. Moscow. Izhevsk: IKI, NIC «Reguljarnaja i haoticheskaja dinamika». 912 p. ISBN 978-5-93972-618-4.

11. G. Haken (1991). Information and self organization. Moscow: Mir. 240 p.

12. A.V. Judenkov, A.M. Volodchenkov, M.A. Judenkova (2019). Cooperative motions of electrons on graphene surface. Engineering technologies and systems. Vol. 29. No. 2. P. 234-247.

13. A.V. Judenkov, A.M. Volodchenkov, L.P. Rimskaja (2020). Mathematical modeling within the potential theory. Moscow.

14. B.P. Abbott (2016). (LIGO Scientific Collaboration and Virgo Collaboration) et al. Observation of Gravitational Waves from a Binary Black Hole Merger. Physical Review Letters. Vol. 116, no. 6. doi:10.1103/PhysRevLett.116.061102

15. B. S. DeWitt (1967). Quantum Theory of Gravity. I. The Canonical Theory. Phys. Rev. 160 (5): 1113-1148. Bibcode: 1967PhRv..160.1113D doi: 10.1103/PhysRev.160.1113.

16. G. Dibitetto and N. Petri (2018). High Energy Phys. 039.

17. Lee Smolin (2001). Three Roads to Quantum Gravity, Basic Books.

18. Loll, Renate (1998). Discrete Approaches to Quantum Gravity in Four Dimensions. Living Reviews in Relativity. Vol. 1. P. 13. Bibcode: 1998LRR.....1...13L. — arXiv:gr-qc/9805049. 


\section{ПЕРЕДАЧА И ЭВОЛЮЦИЯ ИНФОРМАЦИИ НА МИКРОСКОПИЧЕСКОМ УРОВНЕ}

Юденков Алексей Витальевич, ФГБОУ ВО СГАФКСТ, г. Смоленск, Россия, aleks-ydenkov@mail.ru

Володченков Александр Михайлович, Смоленский филиал РЭУ им. Г.В.Плеханова, г. Смоленск, Россия, alexmw20I2@yandex.ru

Римская Лилия Павловна, Смоленский филиал РЭУ им. Г.В.Плеханова, г. Смоленск, Россия, lilirimska@yandex.ru

\section{Аннотация}

Для успешного развития информационных технологий необходимо параллельное развитие фундаментальных направлений в теории информации. Известно, что для сложных макроскопических систем эволюцию информации можно моделировать, используя основные законы термодинамики (второе начало термодинамики и т.д.). В тоже время до сих пор неизвестно, распространяются ли основные положения теории информации макросистем на микросистемы. В работе предлагается математическая модель дискретного фазового пространства, которая приспособлена для описания эволюции информации (энтропии) микроскопических систем. Модель дискретного фазового пространства основана на принципе неопределённости и основных свойствах дискретных марковских систем с непрерывным временем. Основным математическим аппаратом для исследования модели являются уравнения Колмогорова. Предложенная модель имеет наименьший масштаб, который может воспринимать внешний макроскопический наблюдатель. Данный масштаб можно интерпретировать как квазиклассический уровень. В результате исследования модели получены следующие результаты. Выяснена структура фазового пространства элементарного сигнала. Показано, что энтропия микроскопической системы возрастает, то есть для микроскопических систем выполняется второе начало термодинамики. Получен переход от микроскопической модели к макроскопической, что доказывает ее адекватность. Развитие модели дискретного фазового пространства имеет достаточно хорошие перспективы. Так с её помощью можно изучать физические системы "частица + поле". Подход, предложенный в построении модели, позволит рассматривать на квазиклассическом уровне электромагнитные и гравитационные поля. Модель дискретного фазового пространства и ее применение для изучения эволюции микроскопических систем является оригинальной разработкой авторов.

Ключевые слова: фазовое пространство, марковский процесс, квантовая теория поля.

\section{Литература}

І. Арнольд В.И. Математические методы классической механики. 3-е изд. М.: Наука, 1989. 472 с.

2. Вентцель Е.С., Овчаров Л.А. Теория вероятностей и её инженерные приложения. 2-е изд. М.: Высшая школа, 2000.480 с.

3. Володченков А.М., Юденков А.В., Римская Л.П. Квантование информации в симплектическом многообразии. В сборнике: Социальноэкономическое развитие региона: опыт, проблемы, инновации. Материалы VI Международной научно-практической конференции в рамках Плехановской весны и II0-летия университета. Министерство образования и науки российской федерации; Российский экономический университет имени Г.В. Плеханова Смоленский филиал. 2017. С. 4I-46.

4. Горелик Г.Е. Матвей Бронштейн и квантовая гравитация. К 70-летию нерешённой проблемы // Успехи физических наук. Том I75. № I0. С. $1093-1108$ (2005).

5. Грибов В.Н. Квантовая электродинамика. Ижевск: РХД, 200I. 288 с. ISBN 5-93972-089-7.

6. Ландау Л.Д., Лифшии Е.М. Теоретическая механика. Т.З. Квантовая механика. М.: Наука, 1989. 768 с.

7. Ландау Л.Д., Лифшии Е.М. Теоретическая механик.а Т.5. Статистическая механика. М.: Наука, 1989. 626 с.

8. Оксендаль Б. Стохастические дифференциальные уравнения. М: Мир, "Издательство АСТ", 2003. 408 с.

9. Окунь Л.Б. Физика элементарных частиц. 2-е изд., перера6. и доп. М.: Наука, 1988. 272 с. ISBN 5-02-0I3824-X

10. Пенроуз Р. Путь к реальности, или законы, управляющие Вселенной. Полный путеводитель = The Road to Reality: A Complete Guide to the Laws of the Universe / Пер. с англ. А. Р. Логунова, Э. М. Эпштейна. М.-Ижевск: ИКИ, НИЦ "Регулярная и хаотическая динамика", 2007. 912 с. ISBN 978-5-93972-618-4.

II. Хакен Г. Информация и самоорганизация. Макроскопический подход к сложным явлениям. М.: Мир, І99І. 240 с.

12. Юденков А.В., Володченков А.М., Юденкова М.А. Согласованные движения электронов на поверхности графена // Инженерные технологии и системы. 2019. Т. 29. № 2. С. 234-247.

13. Юденков А.В., Володченков А.М., Римская Л.П. Математическое моделирование на основе теории потенциала. Москва, 2020.

14. Abbott B.P. (LIGO Scientific Collaboration and Virgo Collaboration) et al. Observation of Gravitational Waves from a Binary Black Hole Merger // Physical Review Letters. 2016. Vol. 116, no. 6. doi:10.1103/PhysRevLett.116.061102

15. DeWitt B.S. (1967). Quantum Theory of Gravity. I. The Canonical Theory // Phys. Rev. I60 (5): III3-II48. Bibcode: I967PhRv..160.III3D doi: 10.1103/PhysRev.160.1II3.

16. Dibitetto G. and Petri N. // High Energy Phys. 2018, 039.

17. Lee Smolin, Three Roads to Quantum Gravity, Basic Books, 200I.

18. Loll Renate. Discrete Approaches to Quantum Gravity in Four Dimensions (// Living Reviews in Relativity. 1998.Vol. I. P. 13. Bibcode: 1998LRR..... I...I3L. - arXiv:gr-qc/9805049.

Информация об авторах:

Юденков Алексей Витальевич, заведующий кафедрой менеджмента и естественно-научных дисииплин, д.ф.-м.н., профессор, ФГБОУ ВО СГАФКСТ, г. Смоленск, Россия

Володченков Александр Михайлович, заведующий кафедрой естественнонаучных и гуманитарных дисииплин, к.ф.-м.н., доцент, Смоленский филиал РЭУ им. Г.В.Плеханова, г. Смоленск, Россия

Римская Лилия Павловна, доцент кафедры менеджмента и таможенного дела, к.ф.-м.н., доцент, Смоленский филиал РэУ им. Г.В.Плеханова, 2. Смоленск, Россия 